\title{
Covid-19 fatality is likely overestimated
}

\author{
Joshua D Niforatos resident physician ${ }^{1}$, Edward R Melnick assistant professor ${ }^{2}$, Jeremy S Faust \\ instructor in emergency medicine ${ }^{3}$
}

${ }^{1}$ Department of Emergency Medicine, Johns Hopkins School of Medicine, 1830 E Monument Street, Suite 6-100, Baltimore, MD 21205, USA; ${ }^{2}$ Department of Emergency Medicine, Yale School of Medicine, New Haven, CT, USA; ${ }^{3}$ Department of Emergency Medicine, Brigham and Women's Hospital, Boston, MA, USA;

The final case fatality rate (CFR) from SARS-CoV-2, the virus that causes covid-19, will likely be lower than those initially reported. ${ }^{1}$ Previous reviews of H1N1 and SARS show the systematic inflation of early mortality estimates. ${ }^{23}$ Early estimates of H1N1's mortality were susceptible to uncertainty about asymptomatic and subclinical infections, heterogeneity in approaches to diagnostic testing, and biases in confounding, selection, detection, reporting, and so on. ${ }^{23}$ These biases are difficult to overcome early in a pandemic. ${ }^{3}$

We read Xu and colleagues' report of 62 cases of covid-19 outside of Wuhan, China, with interest, as no patients died in the study period. ${ }^{5}$ Compared with a report of the 72314 cases throughout China, the marked differences in outcomes from Hubei (the province of which Wuhan is the capital) compared with all other provinces are worth a brief discussion. ${ }^{4}$

The CFR in China (through 11 February) is reported as $2.3 \% .^{15}$ The CFR among the initial Wuhan cohort was reported as $4.3 \%$, with a rate of $2.9 \%$ in Hubei province. ${ }^{15}$ But outside Hubei the CFR has been $0.4 \%$. Deaths occurred only in cases deemed "critical." Importantly, the CFR from these reports is from infected, syndromic people presenting to healthcare facilities, with higher CFRs among older patients in hospital (8\%-14.8\% in the Wuhan cohort).

As accessibility and availability of testing for the novel coronavirus increases, the measured CFR will continue to drop, especially as subclinical and mild cases are identified. ${ }^{6-8}$ Alternatively, the CFR might not fall as much as in previous epidemics and pandemics, given the prolonged disease course of covid-19 or if mitigation measures or hospital resources prove inadequate. $^{9-12}$

As with other pandemics, the final CFR for covid-19 will be determined after the pandemic and should not distract from the importance of aggressive, early mitigation to minimise spread of infection.

Competing interests: None declared.

Full response at: https://www.bmj.com/content/368/bmj.m606/rr-5.

1 Wang D, Hu B, Hu C, etal . Clinical characteristics of 138 hospitalized patients with 2019 novel coronavirus-infected pneumonia in Wuhan, China. JAMA 2020; 10.1001/jama.2020.1585. 32031570

2 Wong JY, Kelly H, Ip DK, Wu JT, Leung GM, Cowling BJ. Case fatality risk of influenza A (H1N1pdm09): a systematic review. Epidemiology 2013;24:830-41. 10.1097/EDE.0b013e3182a67448. 24045719

3 Lipsitch M, Donnelly CA, Fraser C, etal . Potential biases in estimating absolute and relative case-fatality risks during outbreaks. PLOS Negl Trop Dis 2015;9:e0003846. 10.1371/journal.pntd.0003846. 26181387

4 Wu Z, McGoogan JM. Characteristics of and important lessons from the coronavirus disease 2019 (covid-19) outbreak in China: summary of a report of 72314 cases from the Chinese Center for Disease Control and Prevention. JAMA 2020; 10.1001/jama.2020.2648. 32091533

$5 \mathrm{Xu} X W$, Wu XX, Jiang XG, etal . Clinical findings in a group of patients infected with the 2019 novel coronavirus (SARS-Cov-2) outside of Wuhan, China: retrospective case series. BMJ 2020;368:m606. 10.1136/bmj.m606 32075786

6 Majumder M. Case fatality rate (CFR) is time- and population-varying (Tweet). 2020. https://twitter.com/maiamajumder/status/1235219601232887808.

7 Deng X, Yang J, Wang W, Wang X, Zhou J, Chen Z, Li J, Chen Y, Yan H, Zhang J, Zhang $\mathrm{Y}$. Case fatality risk of novel coronavirus diseases 2019 in China. medRxiv 20031005 [Preprint] 6 Mar 2020. https://doi.org/10.1101/2020.03.04.20031005.

8 Omori R, Mizumoto K, Nishiura $\mathrm{H}$. Ascertainment rate of novel coronavirus disease (COVID-19) in Japan. medRxiv 20033183 [Preprint]. 10 Mar 2020. https://doi.org/10.1101/2020.03.09.20033183

9 Ding Y, Luo S, Zheng X, Ling P, Yue T, Liu Z, Weng J. Association of population migration and coronavirus disease 2019 epidemic control. medRxiv 20024661. 20 Feb 2020. https://doi.org/10.1101/2020.02.18.20024661.

10 Anderson RM, Heesterbeek H, Klinkenberg D, Hollingsworth TD. How will country-based mitigation measures influence the course of the COVID-19 epidemic? Lancet 2020; 10.1016/S0140-6736(20)30567-5. 32164834

11 Remuzzi A, Remuzzi G. COVID-19 and Italy: what next? Lancet 2020; 10.1016/S0140-6736(20)30627-9. 32178769

12 Dalton C, Corbett S, Katelaris A. Pre-emptive low cost social distancing and enhanced hygiene implemented before local covid-19 transmission could decrease the number and severity of cases. SSRN 2020;3549276. 10.2139/ssrn.3549276.

Published by the BMJ Publishing Group Limited. For permission to use (where not already granted under a licence) please go to http://group.bmj.com/group/rights-licensing/ permissions 